\title{
ATTENDING A NATIONAL CONVENTION AND SEEING IOWA
}

John Insley Blair, builder and business man, whose name is high on the honor roll of makers of Iowa, caught sight of the green hills of this state when he and other delegates to a great national political convention, penetrated the then far west on a joy ride eighty-four years ago. From an excursion steamboat his keen eyes surveyed the land west of the big river, as they took the easy trip from Dubuque to Clinton. He liked what he saw, and he came back three years later as a scout on the lookout for a good place to locate and build a railroad to the west across Iowa.

This little journey into the comparatively young state of Iowa was in the pleasant month of May, the year 1860, when the war was not yet started, but the rumblings were much in evidence and the hopes of all were upon the life of peace. Most certainly on this first excursion a little way into the new state the politico-excursionists from the Atlantic seaboard indulged in an exchange of ideas about the opportunities for business, and there was gossip about how and where railroads would be built to turn these opportunities into realities. That was the very purpose of the excursion and the distribution of free tickets and giving of joyous banquets. The party of delegates and their wives and friends, came by way of Galena, then a city of much importance, paused at Dubuque and Clinton and came as far as Cedar Rapids. That was at the time when the western limit of railroad building was in Iowa. Only preliminary work from there on had been done. But the time was ripe for track laying.

At the time of this excursion into Iowa, Mr. Blair was 58 years old. He was a farmer's son, became a merchant, engaged in the manufacture of iron, and was already prominent in the building of railroads. In due time he had a hand in building several railroads in Iowa, a total of 803 miles. Eventually he also controlled 1035 miles of railroad in Iowa and Nebraska alone, and such was his 
intense activity that he was a director in thirty railroad companies, and a stockholder in probably seventy-five.

This chapter has to deal, however, with one little incident in his political life. In view of his extensive business interests, it seems strange that he took time to be a delegate to a Republican national convention, and even went farther, becoming a candidate for governor of New Jersey, his home state, in 1868.

\section{an Historical Journal of Travels}

There came into possession of the State of Iowa, for its Historical department and valuable collection of historical materials, a copy of the travel journals of John I. Blair, and the original journal of that portion which pertains especially to Iowa. Just one chapter in this interesting journal is given herewith exactly as Mr. Blair wrote it out at the time, word for word, mistakes in spelling and everything. This is the chapter of his remarkable trip to attend the convention which nominated Abraham Lincoln for the presidency. It was at this time he first saw Iowa. The journal will show how it came about.

This original journal of early day travel came to the department by favor of Dr. William Penn Vail, of Blairstown, N. J. and his brother Dr. J. I. B. Vail, of Hyannis, Mass. As members of the Blair household, they decided that inasmuch as at least one chapter of the Blair record referred to a journey into Iowa and Nebraska, the capital of Iowa was the proper place to deposit it for preservation. They also sent a transcript of the portions relating to other and sundry journeys, including the convention trip and side excursion into Iowa. This being another year for the outburst of national politics it is highly appropriate to here and now publish for the first time this story of the convention of 1860. The Blair experience will afford a fine contrast in many ways to a similar journey to a convention in Chicago at this time.

The care with which the man who afterwards became very rich set down every little item of expenditure on 
this journey to a national convention was characteristic of the individual. That is the way he became a millionaire. That is the way he built railroads without waste. His political thinking probably was just as carefully planned and carried out.

Mr. Blair was on the New Jersey Republican delegation, which went to Chicago to secure, if possible, the nomination of William L. Dayton. On the first ballot of the convention the New Jersey vote of fourteen was cast for Dayton. Despite efforts to secure other votes, none were forthcoming for the New Jersey favorite. Mr. Blair had been at the head of a committee which interviewed other delegates on behalf of their candidate. On the second ballot, four of the New Jersey votes went to Wm. $\mathrm{H}$. Seward, then the most conspicuous of the candidates, and ten stayed with Dayton. On the third ballot the record showed five for Seward and eight for Lincoln, one delegate not recorded.

That was the hour of great decision, and of much confusion, at this momentous convention, for the tally sheets showed Mr. Lincoln just a vote and a half short of the nomination and more than fifty ahead of the New York governor. The phenomenon of "changing the vote" quickly ended the suspense and the Illinois man was nominated. All this is familiar to the historians of the times, but is always well worth repeating.

It is evident from the journal of $\mathrm{Mr}$. Blair printed herewith that he, at least, was not greatly dismayed by the failure of his home state to put over a favorite son. He took a trip to Springfield to tell the nominee that he would come to Washington and greet him there at the time of the inauguration, and quite likely he did just that. At Springfield he found the nominee "very temperate" and that "he neither drinks rum, chews or smokes." And so Mr. Blair returned home quite happy and dead sure of how and where every cent had been spent by him on the trip. He was a delegate to other and later national conventions, and between his railroad 
building and other interests he was a busy man during the 97 years of his life. ${ }^{1}$

\section{JOHN I. BLAIR'S OWN STORY}

The record which follows is the literal copy of the Blair journal, all kept in his own hand on the small pages of a cheap note book. Mr. Blair was the son of a farmer and attended school but a short time. Printing the words and lines just as written does not reflect upon him in any way, but rather shows in a most striking manner the American genius for achieving greatly despite handicaps. The story of the attendance at the Chicago convention and the side trip into Iowa, just prior to the dark days of the Civil war, follows:

Blairs Town, May 7th, 1860.

J. I. Blair, as a Senatorial Delegate of the $3 \mathrm{~d}$ District of N. J. to the National Republican Convention at Chicago, to be held the 16th May 1860 .

left Blairstown by way of New York, with Mrs. Blair. after Transacting the Business in New York on Tuesday -Took Carriage at Mr. Charles Scribners for the Hudson River Rail Road, to the Depo, Foot 31st Street.

Here I Procured Special Tickets for the Convention, by Way Albany-Suspension Bridge Detroit \& thence Via Michigan Central to Chicago. I paid for Ticket Myself \& Mrs Blair to go \& Return, by 1 June $1860, \$ 66.00$; the original Price for that Distance \& Return, is $\$ 24$. or $\$ 96.00$ Reduced to $\$ 66-A$ Saving of $\$ 30.00$ if We Return the Same Way, or Via Southern Road to Buffaloo.

We left New York 5 1/2 Oclk PM, arrived at Albany 10 Oclk. PM put up at the Delaware House Albany. First Class Hotel. Had Super Lodng \& Breakfast Bill \$4.50. Had First Rate room \& parlor, No. 62 \& 63-

\footnotetext{
The story of John I. Blair's life is a part of the history of American business and railraad building. His political interests were secondary. His religious life was never submerged. The journal of his trip to a national convention shows that he saw the commercial side of the picture as he went along. It also reveals his constant interest in the Presbyterian church. While he contributed largely to its support, his line is not that of the eminent Presbyterians, Rev. Samuel Blair and Rev. John Blair, both trustees. of Princeton University, and the former being president before Dr. Witherspoon. (v. Thomas Vail-Salem 1640, p. 441) Mr. Blair's father died in 1816 when John $I$. was 14 years of age. His mother survived until 1857 .
} 
left in the Morning 9th May, 7 1/2 Oclk for Suspension Bridge, thence Via Great Western Rail Road to Detroit. Took Dinner at Syracuse pd \$.80c Bot Book \& \$.50c. arrived at Suspension Bridge at 8 Oclk. P.M. Took Tea at Central Hotel Near Depo. \& paid $\$ 1.00$

Nothing Occurred to Mar the Ride except the Porter at Delaware House Brot our Trunks to the Depo \& the Baggage Man checked them Both-Promised to put them in the Baggage Car - as the Train left, I Saw Mrs Blairs Trunk in the Hand of Some one, I took to be the Baggage Master. On arriving at Schenectady, I Telegrath Back for the Trunk, Number Check 4410_-Trunk Marked A.B. Rcd [Rec'd] a Despacth it would be Sent on to Suspension Bridge by the express, that arrived at 10 Oclk. P.M. which was as Soon as We Could leave for Detroit. the day Was Some Rainy \& Warm and No Dust.

I wrote letters at Albany to Wm. R. Humphry, Ithaca about the Reffrnce (Referee) in the Case of Jacket. Presidnt Gale from Home. Want adjournment for 40 days.

Wrote Charles Scribner enclosed letter to James Blair to Send Anna Blair his daughter to Europe, with Clinton \& Aulia (Aurelia). Wrote Marshal Hunt to get what Money out Package James Blair would get Park Bank.

We left Albany 7 1/2 Oclk. A.M. We arrived Suspension Bridge at 8 Oclk. P.M. after taking our Tea the express Train from Albany arrived. I Immediately Went to enquire whether the Missing Trunk had arrived: which I ascertained Was the Case. Mrs. Blair Concluded We had better Take the evening Train 10 1/2 Oclk, and go through to Detroit that Night. So We Ticketed our Baggage through to Detroit. and took the Train by the Great Western Rail Road-Through Canada for Detroit. We Took the Car with high Black Sleeping Chairs-which was Very Comfortable. We had a large Blanket, Shawl, to lay over our laps, So that we passed the evening Travel from the Suspension Bridge to Detroit Distance [?] Miles.

We arrived at Windsor opposite Detroit at 7 Oclk A.M. 
Next Morning, Thursday 10th, We Took the Ferry Boat leading to the Depo of the Detroit \& Millwaukee Rail Road. Took Breakfast on the Boat, and paid $\$ 1.00$. We Took the Millwauke \& Detroit Rail Road for Drayton Plains Station, 32 Miles West of Detroit, in order to Visit My Sister, Mrs John M. Fair. We arrived at Pontiac, 25 miles Distance from Detroit. here we Stoped an hour, untill the arrival of the Second Train. Took the Omnibus, and Rode through Pontiac, Sufficient to See the place. Returned to the Station, paid Omnibus 50c.

Thence We took Train 8 Miles Drayton Plains, which was within 1/4 Mile of J. M. Fairs House. the Rail Road passes through his Farm. I found here a wagon, who took Mrs Blair, Myself \& Trunks to Mr. Fairs, where we arrived at about 10 Oclk on Thursday. Found Mrs Fair \& all the Family Very Well, all enjoying good Health. After Taking Dinner, Mr. \& Mrs Fair Proposed Taking a Ride in their Carriage to Clarkson to See Wm. K. Axford, and Elen his wife, and old Favorite acquaintance of mine. Ellen, the wife of Wm. K. Axford, was Formerly a Resident of Oxford Furnace ${ }^{2}$-her father \& Mother Was old intimate acquaintances of My Father \& Mother. She was always Considered when in New Jersey Very Intelligent, and So Well Versed in Political Matters that She was Much admired on that Score.

Wm. K. Axford is a man of Great Influence, and Considerable Wealth, is the Principal Man of the Village of Clarkson-Something of a Pollitician Very Much Respected, has been a Member legislature-Many Years a Merchant: Now has Retired from Business. Axford is a Democrat, his wife is Republican. She was an ardent Clay Whig in N. J. I found her greatly Beloved in her Village, on account her generous Treatment of the Sick. Scarcely any person that Dies in that Region Mrs Axford is Called uppon to purchase or Pick out every thing Suit-

\footnotetext{
${ }^{2}$ Oxford Furnace, as the name suggests, is in the iron district of northwestern New Jersey where the iron industry was well under way prior to the American Revolution. Mr. Blair later became much interested in iron production. The name of the place is a corruption of Axford rather than being named for Oxford, England. See Pioneer Families of Northwestern New Jersey, by Wm. C. Armstrong, Article 21.
} 
able for the Deceased, in the family her advice Taken.

all this Section of County, Oakland County, is Mainly Settled by Jerseymen from Warren \& Sussex County. I can Count 50 families or More, that is from Warren County. The lands lays Very level. Clear of Stone. Very easy farmed. the Wheat and Corn looks Remarkable Well. Clarkson Village, about 4 miles West of Fairs. Waterford Village about one Mile. Called to See John Robatson (?) \& Lady his wife is a Cousin of Saml Blairs wife, Osborn. I find all our Jersey people have good farms. Mr. John M. Fair has a Very excellent farm, his wheat Very fine. every thing for a farmer Full and plenty: all enjoying Good Health-his farm is So near the Depo Makes it Very Convenient. We Spent with Mr. Fair Thursday \& Friday-afternoon, 5 Oclk. P. M. when We Took the Cars From Drayton Station to Detroit, where we expect to Stay all Night, and Then leave Satturday Morning the 12th. for Chicago.

Fair from Detroit to Drayton Plains, pd ...................\$ $\$ 2.00$

Fair Back to Detroit. $\$ 2.00$

Bill of expenditures Since I left New York City, Carriage from Scribners

Rail Road Charges to Chicago and Return

Bill at Albany. $\$ 4.50$

Diner, Syracuse

Tea at Falls

Purchased Book, Description of Falls

Purchased Book, of the Travels Sir John Franklin $\$ 1.00$

Purchased Small Items

Tea on Boat Detroit

Bill RR fair to Drayton \& Return

Paid Waggon to Fairs

and expended to $11 \mathrm{Apl} 1860$,

On leaving I Presented my Sister Catherine.

3 Children \& Servant

Arrived at Detroit Friday evening 7 Oclk PM. Put up at the Russell House a First Class Hotel. Staid all Night. Bill Supper Lodg \& Breakfast \$4.00, extra Including Omnibus \& Trunks 1.00 
Satturday Morning the 12th May left Detroit 7 1/2 Oclk.A.M. for Chicago 284 Miles by Way the Michigan Central Rail Road. Took Dinner Marshall \& paid $\$ 1.00$.

The Villages along the line, Many of them Was quite large \& Flourishing, the Lands lays Generally level, is a Sandy loam, no Stones. the Wheat looked Generally Very Well. at Michigan City on the east end Lake Michigan, is Considerable of a place: the Sand Hills here Drift like Snow in the Windy time. on the Whole it is a Very unpleasant place, on that account. here You have a great View of Lake Michigan, as far as the Eye Can See. Nothing But the Blue Waters-the lake is Generally in View the Greater part of the Distance to Chicago. the land Very level. the Country low \& not much Settled. it is Generally what is Called the Wet Prairie land without Trees. the Michigan Central RR is quite good. the Trip was Pleasant.

We had on the Train Great Many Delegates to the Convention, Many of whom I was previously acquainted with, as well as by Reputation. J. B. Williams esqr. and Mr. George Schuyler of Ithica. Thurlow Weed, ex-Gov. Cleaveland, ${ }^{3}$ Gov. Morrell \& many others.

Arrived at Chicago, 7 1/2 Oclk PM. and Put up at the Richmond House, a First Class Hotel. Rooms had been engaged here for the New Jersey Delegation. many arrived this evening. Was all glad to see each other.Rested quite well Satturday evening. Attended Second Presbyterian Church on Sunday. Found Doctor Dodge here his Son Was Very Sick.

Satturday was fine Day So was Sabbath. Distance Traveled from New York to Albany by way Hudson River Rail Road, say No. 150 Miles.

Albany to Suspension Bridge, Suspension Bridge to Detroit 305 Miles

Detroit to Chicago

${ }^{3}$ Chauncey F. Cleveland, Connecticut legislator and governor; two terms as a Democrat in congress; delegate to the Republican convention in Philadelphia in 1856, and Chicago in 1860 ; presidential elector on the Lincoln-Hamlin ticket. 
Delaware Station to New York

Rail Road from Detroit to Drayton Plains

J. M. Fair \& Back to Detroit

Traveled since We left Home

Monday to Satturday night.

Chicago is one of the Most Remarkable Places in the Western Country, or in the World. Considering the time it has been Constructed. the amt Grain Shipped here, it is the largest Grain Market in the World Some 12 to $\mathbf{1 5}$ Rail Roads Terminate here. the Place Contains about 130000 Inhabitants. the Streets are Laid out Very Wide Some 200 feet all Laid out at Right Angles. the View from the Top of the City Hall is grand. the Town appears to be at least Six Miles long \& Two Miles Wide,-it Covers a great extent of Country. in Consequence of its Wide Streets : a large Poriton of the Buildings, Including Stores \& dwellings equalls New York, Many of them Fifth avenue.

the Flag Stone for the Pavement or Side Walk are unequaled. the main Side Walks are laid with those Stone. the Pavements are Generally 12 feet Wide in the Clear. Some of them 16 feet, or thereabouts. the Flag Stone are got out uniform-say for Some Streets 4 feet Wide 12 feet long 6 Inches Thick, Grey Granite or SandStone. the Joints are fited to Suit exactly, \& halved So as to lap each other: such Perfect pavement, No City in this Country is equal. Some Side Walks are 16 feet Wide, the Fronts is the Same. I saw one Stone, the pavement Stone in front, was $24 \mathrm{ft} 8$ Inches long $15 \mathrm{ft} 3$ Inches wide, 6 Inches Thick, it Weighed 25 Tons. Cost $\$ 300$. laid down.

Theise Stone quarries is Situate 25 Miles South of Chicago was found when the Illinois Canal was Constructed. The Canal passed through this Rock Cut about 10 Miles. Some places the Cut is 20 feet deep, the Canal is quite large-Boats Carry 150 Tons. it extends from Chicago to Illinois River, by the River to the Mississippi : which makes a Water Communication from the Mississippi to the lake. there is no doubt but this Rock Cut, at 
Joliet, was once the Shore of the lake-the Waters Near this place Divides. one part goes to the Mississippi the other to the lake-

the Singular formation of this Stone is Remarkable. they lay lavel, and can be Taken out any length the layings are Regular, from 3 Inches to 2 feet Thick. the Top of the Ground or Surface Marks No Indication of any Stone in the Country.

Some Years ago the Builders sent to lock Port New York-They Supposed there was no Stone in the Country, except a Mound or quarry of Bittuminous Lime Stone, found on the Praries. Some 15 Miles from Chicago, which quarry they used in Constructing the Second Presbyterian Church N.S.-it is a Large Building, High Spirethe Stone gives it a Very old appearance the lime Stone is dark; the Sun has drawed the Pitch out of the Stonewhich gives it the appearance of Spots of Pitch or Tar, Spaterd all over-it looks if it was 1000 Years old-it is Noted as one of the Curiosities of the Place, in the Travelers guide-

the Hotel accommodations in this place is extensive. On the examination previous to accommodate the Convention it was found they had Room for 15.000 Persons.

The Place is Supplied with Gass and Water. the Water is Taken from the lake by the Pumps, \& drawn in Basons, or Buildings Prepared to have it at Some Highth; from these Reservoirs, it Runs in pipes through the Town.

the Corporation has fixed a Definite Highth for all the Streets, to be filed up to, so that New Houses now are Constructed to Conform to that line, while those owning Houses erected before are Compelled to Raise them to Conform to the Street-on them lower Story is Closed up.

the process of Raising Houses is going on Continualy. So is the filling up the Streets. the unevenness of the Streets makes it Wearisome to Travel, as You are Continually Walking up Some Several feet \& going down the Same-the Plan of Sewerage is Commenced,-as Soon 
as the Streets are Raised, the Pavement and Sewards Completed, I think the place will be Healthy \& Pleasant.

The Illinois Canal, Coming in at Chicago, as well as the Chicago River, Coming in the lake here, Runing through the Centre of the Town here, makes a great Harbour for all Kinds Vessels. the Docks on each Side the River and Canal Can be extended back Several Miles, So there will be no Want of Dock Room. the Place now depends uppon agriculture-No Manufactures.

Now as to the Convention. They generally arrived Monday evening - those of N.J. all Came on Monday evening. all at Richmond House. the New Jersey Delegation had as their Rondesvous double Parlours adjoining the Richmond House, access to them out of Richmond House by a doorway Prepared for that Purpose.

Our N. J. Delegation organized, ${ }^{4}$ agreed to meet every day at Nine \& 4 Oclk-We appointed Committees to Confer with Delegates from other States, to advance the Choice of our Delegation for Prest. Wm. L. Dayton of N. J. J. I. Blair, Dudly J. Gresay (?), Ephriam Marks, Thos J. Dudly appointed for that Purpose-We had Conference with the Delegation from Pa, Ohio, Maryland, Delaware, Kentucky Illinois Indiana, Vermont Rhode Island, Massachusetts Maine Iowa Wisconsin \& Many other States.

Our Delegation agreed to Vote Solid for Dayton, which We did the First Time; and afterwards to be governed by Circumstances.

8 of our Delegates Determined not to Vote for Sewart; 6 for Sewart.

The Convention organized Wednesday 16th May. George Ashmun of Massachusetts Chairman, with Vice Presidents from Every State.

Wednesday \& Thursday was Taken up in the organiza-

\footnotetext{
4The New Jersey delegation included several who had been delegates also to the Republican national convention in Philadelphia in 1856-Gregory, Waterman. Duer, Dudley and perhaps others. Sherman had signed the call for the Chicago convention as committeeman for New Jersey. On the committee on permanent organization was Ephraim Marsh: on credentials, Moses $F$. Webb: on business, H. S. Congar; on resolutions, Thos. H. Dudley; vice president, E. Y. Rogers; secretary, Edward Brattie. On the new national committee was named Denning Duer of New Jersey.
} 
tion \& platform, after this was done arrangements was Made for Voting.

the First Vote all the Candidates got Votes, many of them Complimentary. Seward got 173 Votes, Lincoln 102: Dayton 145: Bates 49: Cameron 54-Houston, Wade, Chase \& others also got Votes, with Judge McLean.

the Seward Men was quite Confident on the Second Vote. 8 from N.J. \& Part of Pa. Went for Lincoln, which Commenced Turning the Scale. the Next Time the Border States with all the Conservative part of New England, Came out for Lincoln, which gave him the Majority other States Came in.

New York Was greatly disappointed, but afterwards Came in-the other Delegations then desired New York to nominate the Vice President. this they declined formerly to do, but the Majority Voted for Hannibal Hamlin of Maine-the Second Vote Made him unanimous: a Committee from each State Was appointed to Wait on Mr. Lincoln Personally, and Notify him of the Nomination: which was Performed. E. Marsh of N.J. on her part.

Friday was Taken up at entervals by Speaking.

The Meeting of the Delegates Was held in the Republican Wigwam-Constructed on Purpose for the Convention, estimated to hold 12000 persons. it was filled to the utmost, there was \& equal Number outside. During the Voting each Vote was announced to those outside by arrangement from Telegraph. So all had and opportunity to hear.

the House was lighted with Gass, the utmost order and Decorum was observed. Ashmun made and Able Presiding Officer.

Polliticians had but little Influence. the Delegates appeared animated with but One Mind. That Was to Take No Trading Politicians. Lincoln \& Hamlin are Such Men Taken from the People. ${ }^{6}$

\footnotetext{
${ }^{\circ}$ William L. Dayton had been member of the New Jersey supreme court and two terms a United States senator, later United States minister to France. He was the nominee for vice president on the Republican ticket in 1856. He was a staunch Whig and an outspoken advocate of the abolition of slavery.

${ }^{\circ}$ For a more detailed account of the convention proceedings $\nabla$. McMaster, History of the People of the United States, Vol. VIII, p. 452 et seq; and J. F. Rhodes' History of the United States, Vol. II, p. 412 et seq.-W. P. V.
} 


\section{JOURNAL DESCRIBES IOWA TRIP}

During the Sitting of the Convention and Invitation Was Read From the Presidents of the Gallena and Chicago Union Rail Road and from the Steam Boat Company from Dubuque to Clinton, and From Clinton to Cedar Rappids on the Iowa Central \& Nebraska Rail Road. Thence Return on the Chicago \& Fulton Rail Road-the excursion to Take place on Monday 21st May, which was accepted. the 21st May at $71 / 2$ Oclk Repaired to the Depo. Some 300 Delegates Many with Ladies took the Cars for Dubuque by Way the Galena \& Union Rail Road. from Chicago to Dubuque on the West Side of the Mississippi is 188 Miles. Fulton lays this Side River.

every Village We passed Was overrun with People. Drums firing of Cannon at every place. Some of the Towns there was Thousands.

at Rockford there was 600 Young ladies with Senal Schools all arranged Military, \& other Displays, with Speakers \&c.

We arrived at Dubuque, on the West Side Missipi: We was Recd by the Mayor \& Common Council Military Citizens \& Several Thousand of the Inhabitants. the Mayor Rcd us with a Speech \& he was answered on our part in Speeches. after Marching Round the Place. Took Dinner at the Hotel-those that the Hotel could not accomodate was accomodated Free at Private Houses.

Myself \& Mrs Blair Stoped with Randall, President State Bank Branch, Iowa. We had Speaking in the Court House untill 12 Oclk P. M. Dubuque is quite a large place Said to Contain 10000 Inhabitants. Fulton on the Illinois Side quite a place.

Gallena is quite a place, it is the Lead Region. the lead Region is about 50 Miles in extent. the land about Gallena \& Dubuque is quite Broken thrown up. the lead is found in Seams Said to Run up \& down, in Crevices while the lime Stone Rock lays Horizontal, it Seems. If the lead has to be Melted by some process and Thrown up-it is quite Pure, say 80 to 90 per cent. Gallina is \& old place, Settled quite early, the Mississippi the Outlet. 
Tuesday Morning. Took the Steam Boat Down the Missispia 75 Miles to Clinton, on the Iowa Side of the River. here We had a grand Reception Military Firing Guns Speaking \&c.

Took the Cars for Cedar Rappids 82 Miles West.

arrived at this place at 7 Oclk. here we was Recd again by the Mayor-Military \& drums. Took Supper at the Hotel. Speaking Till Midnight. those that the Hotel Could Not accommodate took Private Houses, all provided free -I Staid at Hotel.

Next Morning, Wednesday, left Cedar Rappids. Returned to Clinton Crossed the Mississi, took the Cars at Fulton, Via the Fulton \& Chicago Rail Road to Chicago. From Fulton to Chicago 136 Miles; arrived at Chicago at 5 Oclk PM. Stoped at Richmond House.

Distance from Chicago to Dubuque..................... 188 Miles

Down the Misippi to Clinton................................ 75

Clinton to Cedar Rapids........................................ 82

Back to Clinton....................................................... 82

Thence from Clinton or Fulton to Chicago........ 136

Distance

563 Miles

Bill at Chicago During Convention, Richmond House....\$45.00

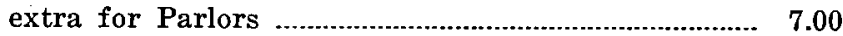

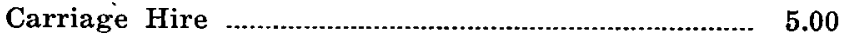

extra for Servants, Shaving \&c................................ $\quad 5.00$

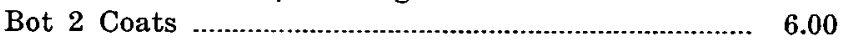

Bill to Dubuque ...................................................... $\quad 2.00$

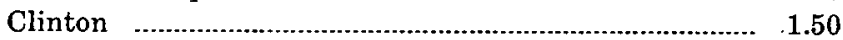

Cedar Rappids ......................................................... $\quad 3.50$

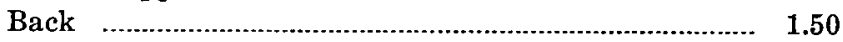

Bill Richmond House ................................................ $\quad 4.00$

Amt

$\$ 80.50$

Thursday Morning 24th May. We left Chicago Via the Chicago \& Alton \& St. Louis Rail Road for St Louis, Via Springfield, Illinois-Distance from Chicago to St Louis 281 Miles. Distance from Chicago to Springfield 184 Miles.

left the Richmond House at 9 Oclk A. M. I Purchased Ticket for Mrs. Blair I paid $\$ 10.00$. R. M. Mason the 
Superintendant Presented me with one for Myself.

We Concluded to go No further than Springfield Thursday, and Stay all Night there, and Call on the Nominee for President, Mr. Lincoln \& his lady. after getting Tea at the Hotel at Springfield, we with Several of the Delegates Called over to see the President \& Lady. We Spent about one Hour with him \& his lady.

We found him quite a plain Man. Very Intelligent \& Cautious, his lady quite Talkative \& Sociable. We left with the Impression that they each Could Fill their Stations With Credit to the Nation.

Mr. Lincoln is Not to be Called Handsome; Sais he is 6 feet $31 / 2$ Inches, Spair \& Bony Indicates a Hardworking man.

his Lady is Short, full face-I told him \& Her when I left that I expected to Call on them at Washington, when they got in the White House, but I Should ask for No Office.

I found he was Very Temperate-they gave us Cold Water, Nothing Else. he Neither Drinks Rum-Chews or Smokes.

left Friday Morning for St Louis, took the Cars 9 Oclk, arrived at St Louis at 3 Oclk P.M. Staid at the Barnum House. Kept in First Rate Stile-Took our Dinner, found it Very Warm. Rode Several Miles about the Town in Rail Road Carg. Saw about What Was to be Seen.

St Lous is Situate on the West Bank of the Missisipi State of Missouri Said to Contain 200.000 Inhabitants ${ }^{8}$ it is a place of Large Business. the drays generally had 2 Mules to each. the Wether Very Warm Thermometer 90.

Satturday Morning. We left St Louis by Way the Alton \& Terehaut Rail Road to Terehaut. thence to Indianapolis, Indiana \& Thence to Cleveland.

We arrived at Indianapolis Satturday 4 Oclk P.M. 262 Miles St Louis. I paid Rail Road fare from St Louis to Cleavland

$\$ 34.00$

BIn 1860 the city of St. Louis was the largest in this region, with 160,780 population. Chicago was credited with 109,203 , Detroit with 45,619 , Indianapolis had 18,612, and Dubuque had 13,060. 
Bill at Springfield \& on the Way............................. $\quad 5.00$

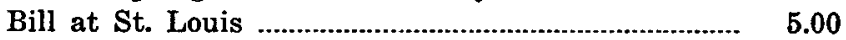

Purchases Mrs Blair ................................................. $\quad 2.00$

Incidentals $\$ 1.00$, Dinner \& Servants $\$ 1$.................... $\quad 2.00$

Rail Road Mrs Blair, Chicago to St Louis................... 10.00

$\$ 58.50$

80.50

99.00

Bill at Indianapolis, Total amt expended

From Satturday till Monday We put up at Indianapolis at the Bates House, a First Class House. We had First Rate Room No. 30.

Distance Traveld to Chicago, See Back, Miles.................1110

to Cedar Rappids .............................. 563

to St Louis from Chicago ................... 281

St. Louis to Terehaute ......................... 189

Terehaute to Indianapolis .................. 73 Miles

Indianapolis to Cleavland 281

Indianapolis to Crestline 206

Crestline to Cleavland ........................ 75

Buffaloo to N. York

Home

Amt of expenditures Brot forward

$\$ 238.00$

Rail Road Fare from Cleveland to Buffaloo ............ 10.00

Bill at Buffaloo

Bill on the way \& Trunks N. York

I Gave Sister Catherine \& Children)

Purchased Coats, Umbrella Mrs Blair)

Spent in New York Riding \&c, I Suppose 
Monday Morning the 28th May 1860. We left the Bates Hotel, Indianapolis for Belfontain and Crestline Ohio, thence to Cleveland, thence down the lake Shore Road to Buffaloo 470 Miles. We arrived at Buffaloo at 10 Oclk P.M. put up at the American Hotel, Kept in good Stile, Called first Class Hotel.

left Tuesday Morning at 5 Oclk for New York, Via Albany, arrived in New York same day at 9 Oclk P.M. We Staid over Sabbath at Indianapolis attended Church, Old School Presbyterian, a fine edifice.

Indianapolis is the State Capital of Indiana a Very Handsome place. Several R. Roads lead from this place to almost every where.

I Shall Now Speak of the Country, and Rail Roads, From Chicago to Dubuque: the Rail Road is good; the Country Very level \& Nearly all Prairie land, except about Gallena, where the Land is Broken. the Villages are all Handsome and New, every one has its fine Church and School Houses. Rockford was the Principal Town on the Way, it was on Rock River, a Very Handsome place and Handsome Country, the Garden Prairies lay Near.

the Prary lands in many places was unbroken like looking on the Sea, the end of Sight. Galena lays Some Several Miles East of the Mississippi-the place is the Seat of the Lead Mines. Large Steam Boats Can Come out the Mississippi to this place, on the Gallena River. at \& early day the Lead Was Shipped down the Missisippi, which is Still done to Considerable extent.

the Supply of lumber is Brot from the Missippi, which Comes down the Missipi from St Paul, Some 500 Miles up. Dunleth lays on the east Bank Missipi. Something of a Town. But it has Seen its day. I do not Think that Towns on the east Bank of the Missipi will generally ever amount to Much Importance, as the Trade maks from the eastWhile the Towns on the West Bank will generally grow, as the Trade Comes in from the West to the River to go East and down the River.

The Steam Boats that We Went down uppon to Clinton and fulton-the land appeared quite level. after You get 
up the River Bank the land layed high enough generally, on each side the River, that It did not overflow the Banks.

Clinton on the West Bank of the Missisipi is a Handsome place. We Took Rail Road there and went out to Cedar Rappids. this was Called I Believe the Chicago, Fulton and Nebraska Rail Road-it leads when finished to the Missouri River about 200 Miles West of Cedar Rapids, or 300 West of the Missisipe-the Land from the Missisipi to Cedar Rappids in Iowa is the Handsomest land I Saw, take it as a whole. ${ }^{9}$

the Prarie laid More Roling, there was Some timber, in places, the land was Rich-The land from Fulton to Chicago is Handsome Prairie land Rich, and much of it Very fine, but Generally level-the Rail Road is good-

I Consider this Road Considering its extension with the land grant on the 200 Miles West of Cedar Rappids, one of the Most desirable and if Rightly Managed ought to pay. It is Connected with the upper Road, from Chicago to Rockford, untill it Reaches the Illinois Central, which goes to Dubuque.

I Consider the Illinois Central of Not Much Account. there is but little Travel North \& South, that on the Galena End goes Generally to Chicago, leaves at the Junction.

the Rail Road from Chicago to Alton and St Louis is quite good. the land from Chicago to Saint Louis is all Prairie land, and Very level, More So than any I Saw. it appears Rich, but too level. this Rail Road passes through Springfield, the Capital of the State Illinois. the Capitol, a Very Nice Stone Building.

Alton is a Nice Town, Considerable Business done-on the Whole this Rail Road will in time do Considerable Business.

We arrived at the Missippi Station opposite Saint Louis here we took omnibus, which drove You on the

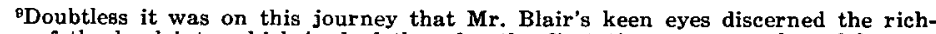
ness of the land into which he had then for the first time penetrated, and he was led to return after three years to further survey the railroad possibilities in Iowa and Nebraska. It is planned that his diary of this later journey also will be published. 
Fery Boat, and then to the Hotel, without getting out,the Omnibus a Very Convenient arrangement, and thence to the Hotel. We put up at Barnums, the Best in Saint Louis.

We Took the Omnibus at the Hotel, Rode on to the Boat Kept our Seat and was Taken to the Cars, on the St Louis Alton and Terehaute Rail Road to Terehaut, thence to Indianapolis, Crestline, to Cleveland, this is said to be the Short Rout to Cleaveland and the east. the land from Saint Louis to Indianapolis is prairie. after leaving Indianapolis we Commenced a Meadow (?) Country, and when we Reached the Ohio line it Was a Wooden Country to Cleavland-Considerable part of the way through Ohio the land is level, and appears Some Clayish. More Inclined to Grass it had Not that deep dark look that the land in Illinois \& Iowa had.

the Settlements looked New Most of the Way, on account the Timber which was Generally Oak Maple \& otherwise. I see no Hemlock or Pine. Many of the Towns appear quite Respectable, but do not equal in appearance the Villages in Iowa, or northern Illinois, or Indiana, or Michigan.

I Notice all the Eating Houses on the whole line from New York to St Louis Charge 50 Cents a Meal. Generally quite fair Cooking. the Hotels all Charge $\$ 2.50$ Cents per day; the Hotels in Nearly all the places is on a large Scale. the Cheapness of produce and the extent of Travel heretofore encouraged that Business I Suppose Caused that Business the leading Business of the Country at that time.

On the Whole, the Whole West is a Wonderful Country in extent, all it Wants is production and Settlement-

the Great proportion of the Settlers Commenced poor, but will Soon by Industry be Well off. they Can at least produce Nearly all they Want; the land Can or May be made a garden. it is Rich \& productive. Speculation has Raised the price of land, and Kept the Country Back, this in time will Cure itself. 
Ohio, Illinois \& Indiana are all Cut up with Rail Roads. You can Settle nowhere except Near a Rail Road.

Various parts of the State all Seemed to have acted to get up each a Rail Road in their Sections \& push for Missisipi, then across Iowa to the Missouri. there is 4 paralel lines Started: the one from Dubuque, one from Clinton $\&$ one from Davenport, and one from Quincy.

the Country is generally Benefitted, but the Roads Will Not Yet all pay; they want population and production. the Roads has Cost double and Treble that what they ought: or they are Maked up-Nearly all the Roads West are in the Receivers Hands. I Suppose the First Bond Holder will Take them-the loss will be large to Many, and a great gain to others. So the Matter Stands.

$I$ arrived Home at Blairs Town after and absence of 26 days, having Traveled 3200 Miles. I met with No accident or Interruptions, nor any delays. the Rail Roads are in good order. All the Western people I found Very Friendly and Communitive.

The people and Villages Seemed to have all the Things that We have east. the Ladies appeared to dress about as expensive as those East, as well as the Men in the Villages.

the population in the Towns generally Come from the old States. Many Brot the Habbits with them, and No Doubt outlive their earnings, With Many Adventures.

the West had a great Many Very Rich Men: the Wealth is Very Unequal, the Brokers or Bankers or those that deal in that line Charge High Rates and use the Money at a High Rate of Interest. those that have large Tracts of land, and Sold them heretofore at high prices have made a large Sum: but they have to give long Credits-

this great West is Calculated to Sustain a great population and in time will give Law \& Legislation to this Country. Prices for all agricultural products Must be less than in the Atlantic States, but land will be Much Cheaper and easier to Subsist a Large population.

Arrived Home, Satturday June 2d 1860.

J. I. BLAIR 


\section{NeW Jersey Delegation SeleCted}

[NOTE: An account of the New Jersey Republican Convention which met at Trenton 8 March, 1860 to choose delegates ${ }^{10}$ for the National Convention to meet in Chicago the $16 \mathrm{May}$, is given in Mr. Blair's Memorandum Book for 1860. This book, a pocket size diary, is written partly with a quill pen and partly with a very fine pointed gold pen--similar to that used by Mr. Blair in his latter years. The writing with the latter is almost microscopic in size, and difficult to read.

This Memorandum Book also contains many notations of a financial character, particularly concerning the Lackawanna \& Bloomsburg R. R., the Warren R. R. and the D. L. \& W. R. R., and various matters concerning the Belvidere Bank, Stocks and Bonds, and notations of trips of a fortnight's duration in Boston, New York and elsewhere to secure subscriptions for various enterprises. I give the record as it is therein found.-W. P. VAIL.]

Republican-or opposition Convention at Trenton, N. J. (under date of $8 \mathrm{March}$ ) Elected Me Senatorial Delegate To National Convention to Meet on the 16th May 1860 at Chicago, For Third District. A. P. Berthoud, District Delegate Congress.

\section{John I. Blair, 3d District. Ephriam Marsh 5th do.}

${ }^{10}$ The New Jersey delegation to the Republican national convention of 1860 , at Chicago, was as reported by the committee on credentials, as follows, quoted in Flower's History of the Republican Party:

Delegates at Large-

James T. Sherman, Trenton.

Thomas $\mathrm{H}$, Dudley, Camden.

Edward $Y$. Rogers, Rahway.

Ephraim Marsh, Jersey City.

F. T. Frelinghuysen, Newark.

Jonathan Cook, Trenton.

Dudley S. Gregory, Jersey Ctiy.

John I. Blair, Blairstown.

District delegates-

1. Providence Ludham, Brighton.

Robert K. Mattock, Woodbury.

Edward Brattie, Camden.

Jonathan R. Ingham, Salem.

2. Archibald R. Pharo, Tuckerton.

Stephen B. Smith, Pennington.

Amzi C. McLean, Freehold.

Bernard Connolly, Freehold.

3. A. P. Bethoude, Washington, war cor.

A. N. Voorhees, Clinton.

Wm. D. Waterman, Janesville.

Moses F. Webb, New Brunswick.

4. Henry M. Law, Paterson.

Wm. G. Lathrop, Boonton.

Thomas Cumming, Hackensack.

Henry B. Crosby, Paterson.

5. Hugh N. Bowne, Rahway.

H. S. Congar, Newark.

Marcus L. Ward, Newark.

Denning Duer, Weehawken. 
David Thompson (District Crongresmn), Thomas $\mathbf{H}$. Dudley 1st Dist., James T. Sherman 2 Dist., Theodore Little 4 do.-Senatorial at Large, Gov. Newell, Theo. F. Freelinghuysen, E. T. Rogers. (and in the back of this book, under the same date, the following)

March 8-Delegates Appointed at Trenton 8 March to go to Chicago 16 May 1860.

1. District. Senatorial, Thomas H. Dudley; Congressional, Providence Ludlam, Robt. K. Matlock, Edward Bettle, Jonathan D. Ingham

2.d. Senat. James T. Sherman; Cong. Archibold Pharo, Stephen B. Smith, A. Mc McClain, Lewis Shinn.

3d. John I. Blair Senatorial. Cong. A. P. Berthoud, A. N. Voorhees, Judge Wm. D. Waterman, Morris F. Webb.

4 Senat, Theodore Little. Cong'l Henry M. Low, David Thompson Wm. G. Lathrop, Thomas Cuming.

5 Senate, Ephriam Marsh, Cong. Hugh Brown, H. N. Congar, Marcus L. Ward, Demming Duer.

Senatorial at Large-Govr. Newell, T. F. Frelinghuysen, E. T. Rogers.

Delegates organized Trenton, E. Marsh Chairman. Appointed J. T. Sherman agent to Procure Hotel \& Parlour for all the N. J. Delegation at Chicago, endeavour to get Rooms for all at same Hotel with Parlor. each paid $\$ 1.00$ to Sherman to Pay Postage-Send Circulars of appointment.

Rooms all engaged for the N. J. Delegation at the Richmond House, Chicago, Commencing Satturday Next Preceding the 16th May; Wednesday-Satturday is 10th May -So writes J. T. Sherman who engaged James M. Redmond of Chicago. Board $20 /$-per day. ${ }^{7}$

[NOTE: The last paragraph is written in a different colored ink from the previous ones, and was evidently entered later.-W. P. V.]

7It is interesting to follow Mr. Blair's use of shillings and pence in tabulating small sums of money. The $20 /$ - above does not represent 20 English shillings, roughly $\$ 5.00$, as one might expect. Rather it is the Spanish or Mexican shilling, the Spanish Real, valued at $121 / 2 \mathrm{c}$. A common name for this coin was a "Bit".hence our expression "Two Bits" for 25c has a well established origin. The Spanish and Mexican coins of various denominations passed currently in America until Congress in 1856 acted to reform the currency by retiring the old familiar Spanish coins in circulation, abolishing the $1 / 2 \mathrm{c}$ piece and authorizing the coinage of nickel cents. (McMaster, History of the People of the United States; VIII, pp. 284-5.) -W. P. V. 
Copyright of Annals of Iowa is the property of State of Iowa, by \& through the State Historical Society of Iowa and its content may not be copied or emailed to multiple sites or posted to a listserv without the copyright holder's express written permission. However, users may print, download, or email articles for individual use. 